\title{
DINAMIKA TENAGA KERJA SEKTOR PERTANIAN DI PROVINSI SULAWESI UTARA
}

\section{EMPLOYMENT DYNAMICS OF AGRICULTURAL SECTOR IN NORTH SULAWESI PROVINCE}

\author{
Olfie L.S Benu; Esry O. Laoh; Sophia L. Montong; Yesi H. Supartoyo
}

Jurusan Sosial Ekonomi Pertanian, Fakultas Pertanian Universitas Sam Ratulangi Manado - 95115

olfie.benu@yahoo.com

\begin{abstract}
The aim of this study was to determine the employment dynamics of agricultural sector in North Sulawesi Province. The research was conducted in Manado (July to August 2010, by using the collecting data as a secondary data research. The data was analyzed using labor share and labor force growth rate. The result showed that labor share of agriculture sector on the basis of education level was dominated by the level of primary education during the period 2007-2009 but its labor force growth rate had decreased each year in both rural and urban areas. On the age group was dominated by the age of 55 years and above. The employment growth rate of agriculture sector was decreased by 5.78 percent each year in the period of 2000-2009. While the fenomena employment in non-agricultural sector was increased by 1.78 percent each year. This result indicated that there was tendency of structural transformation of agriculture sector to non-agricultural sector. The low tendency of trade will be able to influence farmers to reduce or to stop the agribusiness activities that will affect the size of the agiculture labor force share.
\end{abstract}

Keywords: Employment Dynamics of Agricultural Sector

\section{ABSTRAK}

Penelitian ini bertujuan untuk mengetahui dinamika tenaga kerja sektor pertanian Provinsi Sulawesi Utara. Lokasi penelitian di Manado (Juli sampai dengan Agustus 2010). Pengambilan data penelitian berupa data sekunder. Data yang diolah dengan menggunakan perhitungan pangsa (share) tenaga kerja dan perhitungan tingkat pertumbuhan tenaga kerja. Hasil penelitian menunjukkan bahwa pada tenaga kerja pada sektor pertanian sebagian besar memiliki pendidikan sekolah dasar. Kemudian dilihat dari tingkat umur, sebagian besar tenaga kerja di sektor tersebut berumur 55 tahun ke atas. Pertumbuhan tenaga kerja sektor pertanian mengalami penurunan sebesar 5,78 persen per tahun dalam kurun waktu tahun 2000 - 2009. Sedangkan tenaga kerja di sektor non pertanian mengalami peningkatan 1,78 persen tiap tahunnya. Hal ini mengindikasikan terjadi kecenderungan transformasi struktural tenaga kerja sektor pertanian ke sektor non pertanian. Kecenderungan rendahnya Nilai Tukar Petani akan dapat mempengaruhi petani untuk mengurangi atau menghentikan kegiatan usahataninya sehingga akan berdampak pada besarnya pangsa tenaga kerja pertanian.

Kata kunci: Dinamika Tenaga Kerja Sektor Pertanian

Eugenia Volume 16 No.3 Desember 2010 


\section{PENDAHULUAN}

Provinsi Sulawesi Utara pada tahun 2009 jumlah penduduknya kurang lebih 2.228.856 jiwa, kalau dapat dioptimalkan pemanfaatannya dan diserasikan gerak langkahnya, merupakan potensi yang sangat besar, terutama apabila penduduknya mempunyai tingkat pendapatan yang tinggi dan merata. Untuk dapat memberikan tingkat pendapatan yang memadai bagi penduduknya, salah satu cara yang dapat ditempuh adalah menyediakan lapangan pekerjaan yang produktif dan remuneratif yang layak, serta mendapatkan penghargaan dari masyarakat. Misalnya, berupa imbalan atau balas jasa yang diberikan kepada tenaga kerja sektor pertanian sebagai akibat dari prestasi yang telah diberikannya dalam rangka mencapai tujuan.

Pertanian merupakan salah satu keunggulan negara kita yang merupakan negara agraris. Alam Indonesia yang subur merupakan salah satu faktor yang menyebabkan sektor pertanian menjadi unggulan yang memacu pertumbuhan ekonomi terutama di daerah-daerah yang masih mengandalkan sektor pertanian sebagai mata pencaharian penduduk di daerah tersebut. Lebih dari 90 persen kehidupan masyarakat Indonesia bergantung di sektor pertanian dan terbatas sebagai petani penghasil produk pertanian yang bersifat bahan mentah bukan sebagai petani penghasil produk pertanian yang bersifat bahan jadi atau setengah jadi (Bappeda, 2006). Demikian pula halnya dengan Provinsi Sulawesi Utara, berdasarkan wilayah maka kawasan pedesaannya memiliki ciri antara lain sebagian besar penduduk bekerja di sektor pertanian yang secara geologis memiliki tanah yang subur dengan segala tanaman yang menghasilkan berbagai hasil bumi untuk menghidupi masyarakat di daerah tersebut.

Keadaan Agustus 2009, sektor pertanian tetap mendominasi lapangan pekerjaan utama penduduk di Provinsi Sulawesi Utara yaitu sekitar 36,76 persen dari seluruh penduduk yang bekerja. Namun demikian sektor ini mengalami penurunan sebesar 3,43 persen dibandingkan tahun sebelumnya yaitu tahun 2008 .

Perubahan secara besar maupun secara kecil atau perubahan secara cepat atau lambat sesungguhnya adalah suatu dinamika, artinya suatu kenyataan yang berhubungan dengan perubahan keadaan (Soelaiman Joesoef, 1986). Dinamika berupa fakta atau konsep yang mengacu pada kondisi perubahan sehingga bersifat dinamis yang membentuk keteraturan yang jelas dalam hubungan penyesuaian secara memadai terhadap keadaan. Dinamika ketenagakerjaan yang penting diungkap adalah pergeseran ketenagakerjaan. Dengan demikian dapat diungkap melalui empat indikator yaitu tingkat pendidikan, golongan usia, kabupaten/kota dan curahan jam kerja.

Untuk tenaga kerja sektor pertanian sendiri, juga diperlukan analisis berdasarkan usia dan pendidikan. Hal ini bertujuan untuk mengkaji apakah tenaga kerja berusia muda dan memiliki pendidikan lebih tinggi masih bersedia bekerja di sektor pertanian. Serta di tinjau dari curahan jam kerja pada sektor pertanian karena jam kerja dapat digunakan sebagai salah satu indikator produktivitas tenaga kerja. Kemampuan Sumber Daya Manusia (SDM) yang terbatas terutama dari sisi penguasaan IImu Pengetahuan dan Teknologi (IPTEK) serta relatif rendahnya kualitas lingkungan pemukiman pedesaan dan dengan terus bertambahnya jumlah penduduk yang secara signifikan meningkatkan jumlah angkatan kerja, sedangkan di satu sisi luas lahan untuk semua pertanian relatif semakin berkurang, maka penyerapan tenaga kerja yang di sektor pertanian semakin tidak produktif (Disnakertrans, 2007)

Berdasarkan uraian pada latar belakang maka yang menjadi perumusan masalah adalah bagaimana dinamika tenaga kerja sektor pertanian di Provinsi Sulawesi Utara berdasarkan empat indikator yaitu tingkat pendidikan, golongan usia, kabupaten/kota dan curahan jam kerja. Penelitian ini bertujuan untuk mengetahui dinamika tenaga kerja sektor pertanian di Provinsi Sulawesi Utara berdasarkan empat indikator yaitu tingkat pendidikan, golongan usia, kabupaten/kota dan curahan jam kerja.

\section{METODE PENELITIAN}

\section{Metode Pengumpulan Data}

Data yang digunakan adalah data sekunder yang sudah diolah, dalam hal ini berupa data sekunder internal meliputi dokumen dan laporan 
yang diperoleh dari instansi terkait serta data sekunder eksternal meliputi buku literatur yang berhubungan dengan teori yang dibahas.

\section{Konsepsi Pengukuran Variabel}

Data jumlah tenaga kerja sektor pertanian yang digunakan dalam kajian ini merupakan data series dari tahun 2000-2009 yang berasal dari data Survei Angkatan Kerja Nasional (SAKERNAS) yang telah dirilis oleh instansi terkait yaitu Badan Pusat Statistik (BPS), Dinas Tenaga kerja dan Transmigrasi (Disnakertrans), Dinas Pertanian dan Peternakan (Dispertanak) dan Badan Perencanaan dan Pembangunan Daerah (Bappeda). Alasan digunakannya data dari tahun 2000 karena pada tahun ini tenaga kerja sektor pertanian telah diubah standar usianya menjadi 15 tahun ke atas sesuai standar internasional, yang pada tahun sebelumnya usia tenaga kerja sektor pertanian adalah 10 tahun ke atas.

Data series yang digunakan untuk empat indikator (tingkat pendidikan, golongan usia, kabupaten/kota dan curahan jam kerja) adalah dari tahun 2007-2009 yang berasal dari data yang telah dirilis oleh Badan Pusat Statistik (BPS). Alasan digunakannya data dari tahun 2007 karena pada tahun ini keempat indikator tersebut telah diolah dan dikelompokkan secara lengkap, dimana pada tahun sebelumnya belum ada pembagian atas kabupaten/kota. Pengertian tenaga kerja sektor pertanian dibatasi pada angkatan kerja (usia 15 tahun keatas) yang bekerja pada sektor lapangan pekerjaan utama. (1) Jumlah tenaga kerja sektor pertanian berdasarkan tingkat pendidikan yang ditamatkan mulai dari tidak tamat Sekolah Dasar hingga Universitas. (2) Jumlah tenaga kerja sektor pertanian berdasarkan golongan usia dilakukan berdasarkan usia angkatan kerja (3) Jumlah tenaga kerja sektor pertanian berbasis Kabupaten / Kota untuk melihat komposisi tenaga kerja pertanian berdasarkan wilayah (4) Jumlah tenaga kerja sektor pertanian berdasarkan curahan jam kerja untuk melihat jumlah tenaga kerja setengah pengangguran (< 35 jam seminggu) dan bekerja penuh (> 35 jam seminggu).

Penelitian ini dilaksanakan dari bulan Juli sampai bulan Agustus tahun 2010. Tempat penelitian yaitu dilakukan dengan pengambilan data sekunder di instansi terkait di Provinsi Sulawesi Utara.

\section{Analisis Data}

Analisis data dilakukan dengan menggunakan metode statistik deskriptif dan akan disajikan dalam bentuk tabel dan grafik serta histogram kemudian dianalisis secara deskriptif.

\section{Perhitungan Pangsa Tenaga Kerja}

Pangsa atau share dihitung dengan menggunakan metode ( Mubyarto, 2007):

\section{ES}

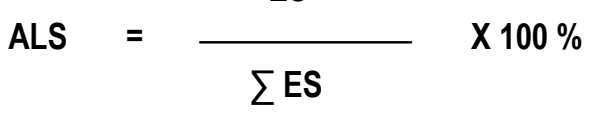

Dimana :

ALS = Pangsa (Share) Tenaga Kerja berdasar indikator pada tahun $\mathrm{n}(\%)$

$\mathrm{ES}=$ Tenaga Kerja berdasar indikator $\mathrm{i}$ pada tahun n (jiwa).

$\Sigma \mathrm{ES}=$ Jumlah Tenaga Kerja pada tahun $\mathrm{n}$ (jiwa).

Perhitungan Tingkat Pertumbuhan Tenaga Kerja(BPS 2008):

$$
\begin{gathered}
P_{t}=P_{0}(1+r)^{t} \\
\frac{\log \left(P_{t} / P_{0}\right)}{t}=\log (1+r)
\end{gathered}
$$

Dimana :

$r$ = Angka Pertumbuhan Tenaga Kerja (\%)

$\mathrm{P}_{\mathrm{t}}=$ Jumlah Tenaga Kerja pada Tahun Akhir (jiwa)

$P_{0}=$ Jumlah Tenaga Kerja pada Tahun Awal (jiwa)

$\mathrm{t}=$ Selisih Tahun

\section{HASIL DAN PEMBAHASAN}

\section{Dinamika Tenaga Kerja Sektor Pertanian dan Non Pertanian}

Pengalaman negara maju menunjukkan bahwa seiring dengan perkembangan ekonomi, jumlah tenaga kerja (orang yang bekerja) di sektor pertanian akan semakin berkurang, sementara yang bekerja di sektor non pertanian semakin bertambah. Fakta menunjukkan bahwa jika kondisi perekonomian negara relatif stabil maka banyak petani mencari alternatif pekerjaan yang lebih baik 
Tabel 1. Penduduk Bekerja Menurut Sektor Lapangan Pekerjaan Utama, Daerah dan Jenis Kelamin di Provinsi Sulawesi Utara, 2009 (Tables 1. Resident Work According To Main Sector Field Work, Area and Gender in North Sulawesi Province 2009)

\begin{tabular}{lcccc}
\hline \multirow{2}{*}{ Lapangan Pekerjaan Utama } & \multicolumn{3}{c}{ Daerah } \\
\cline { 2 - 5 } & Perkotaan & $\%$ & Pedesaan & $\%$ \\
\hline Pertanian, Perkebunan, Kehutanan, Perburuan dan & 45.095 & 12,179 & 300.500 & 52,725 \\
Perikanan & 4.884 & 1,319 & 13.417 & 2,354 \\
Pertambangan dan Penggalian & 25.939 & 7,005 & 31.581 & 5,541 \\
Industri & 2.273 & 0,613 & 1.775 & 0,311 \\
Listrik, Gas dan Air minum & 33.445 & 9,033 & 35.398 & 6,210 \\
Konstruksi & 99.772 & 26,947 & 73.660 & 12,924 \\
Perdagangan, Rumah Makan dan Jasa akomodasi & 52.075 & 14,065 & 40.937 & 7,182 \\
Transportasi, Pergudangan dan Komunikasi & 10.698 & 2,889 & 5.848 & 1,026 \\
Lembaga Keuangan, Real Estate, Usaha & 96.064 & 25,946 & 66.812 & 11,722 \\
Persewaan dan Jasa Perusahaan & 370.245 & 100 & 569.928 & 100 \\
Jasa Kemasyarakatan, Sosial dan Perorangan & & & & \\
\hline Total & \multicolumn{3}{c}{ Sumber: BPS Provinsi Sulawesi Utara, Data Sakernas Agustus 2009 } &
\end{tabular}

sehingga terjadi penurunan jumlah petani, tetapi Tabel 2 jelas memperlihatkan pangsa tenaga kerja di sektor pertanian mengalami penurunan tiap tahunnya selama kurun waktu 2000-2009. Pada tahun 2000 pangsa tenaga kerja sektor pertanian mendominasi pangsa tenaga kerja sektor lainnya yaitu 53,82 persen. Tapi, pada tahun 2001 tenaga kerja di sektor pertanian mengalami penurunan sebesar 5,23 persen sehingga menjadi 48,59 persen dimana hal ini menyebabkan pangsa tenaga kerja di sektor non pertanian melebihi tenaga kerja di sektor pertanian. Adapun salah satu kemungkinan terjadinya penurunan yaitu adanya krisis pangan yang terjadi di seputaran tahun ini. Kemudian pada tahun 2002, terjadi peningkatan sebesar 1,27 persen dibandingkan tahun sebelumnya yaitu tahun 2001 walaupun pangsa tenaga kerja di tahun 2002 tersebut kurang dari pangsa tenaga kerja sektor pertanian di tahun 2000. Kiranya imbas dari membaiknya nilai subsektor tanaman perkebunan mengakibatkan pangsa tenaga kerja meningkat dibandingkan tahun sebelumnya Setelah itu, pangsa tenaga kerja terus mengalami penurunan hingga tahun 2009 dimana pangsa tenaga kerjanya hanya sebesar 36,76 persen. Jika kondisi perekonomian negara kurang baik (misalnya: krisis moneter dan krisis ekonomi) maka terjadi penambahan jumlah petani (Nani, 2003).

Ada banyak faktor yang mempengaruhi penurunan tenaga kerja sektor pertanian selama kurun waktu 2000-2009 salah satu diantaranya yaitu kecenderungan masyarakat yang menaruh minat lebih pada sektor non pertanian yang diharapkan dapat memberi pendapatan yang lebih pasti karena tidak tergantung musim, hal ini ditunjukkan dengan peningkatan tenaga kerja sektor non pertanian yang terus merangkak naik selama kurun waktu 2000-2009, selain itu dengan adanya kondisi perekonomian daerah yang relatif stabil maka banyak tenaga kerja pertanian yang mencari alternatif pekerjaan yang lebih baik sehingga terjadi penurunan pangsa tenaga kerja di sektor pertanian. Penurunan pekerja di sektor pertanian, juga diduga karena penduduk desa banyak yang bermigrasi ke kota, guna mencari pekerjaan dengan pendapatan yang lebih besar. Gambar 1 memperlihatkan dinamika tenaga kerja sektor pertanian yang terus menurun dan sektor non pertanian yang merangkak naik. Tingkat pertumbuhan tenaga kerja sektor pertanian antara. tahun 2000 sampai 2009 adalah $(-5,78)$ persen per tahun. Artinya, antara tahun 2000- 2009 jumlah tenaga kerja di sektor pertanian menurun sebesar 5,78 persen tiap tahunnya. 
Tabel 2. Perkembangan Tenaga kerja di Sektor Pertanian dan Non Pertanian di Provinsi Sulawesi Utara, 20002009 (Table 2. Employment Growth in Agriculture and Non Agricultural Sector in North Sulawesi, Province 2000-2009)

\begin{tabular}{ccccccc}
\hline Tahun & $\begin{array}{c}\text { Pertanian } \\
\text { (Jiwa) }\end{array}$ & $\%$ & $\begin{array}{c}\text { NTP } \\
(\%)\end{array}$ & $\begin{array}{c}\text { Non Pertanian } \\
\text { (Jiwa) }\end{array}$ & $\%$ & $\begin{array}{c}\text { Total TK } \\
\text { (Jiwa) }\end{array}$ \\
\hline 2002 & 397.899 & 49,86 & 275,00 & 400.024 & 50,14 & 797.923 \\
2003 & 399.252 & 49,68 & 131,60 & 404.322 & 50,32 & 803.574 \\
2004 & 429.376 & 49,16 & 161,57 & 444.060 & 50,84 & 873.436 \\
2005 & 399.246 & 47,82 & 161,22 & 435.557 & 52,18 & 834.803 \\
2000 & 590.805 & 53,82 & 241,55 & 506.888 & 46,18 & 1.097 .693 \\
2001 & 357.465 & 48,59 & 383,10 & 378.199 & 51,41 & 735.664 \\
2006 & 341.347 & 41,19 & 143,70 & 487.203 & 58,81 & 828.550 \\
2007 & 373.329 & 41,09 & 133,92 & 535.174 & 58,91 & 908.503 \\
2008 & 362.615 & 39,75 & 101,48 & 549.583 & 60,25 & 912.198 \\
2009 & 345.595 & 36,76 & 101,41 & 594.578 & 63,24 & 940.173 \\
\hline
\end{tabular}

Sumber : diolah dari data sekunder, 2000-2009

Sedangkan tingkat pertumbuhan tenaga kerja sektor non pertanian meningkat tiap tahun sebesar 1,78 persen. Hal ini dapat menggambarkan bahwa terjadi kecenderungan transformasi struktural tenaga kerja pertanian selama kurun waktu 20002009.

\section{Dinamika Tenaga Kerja Sektor Pertanian Berdasarkan Tingkat Pendidikan}

Banyak kalangan berpendapat bahwa salah satu penyebab rendahnya produktivitas tenaga kerja sektor pertanian adalah rendahnya tingkat pendidikan para petaninya. Dengan tingkat pendidikan yang rendah maka adopsi teknologi tidak berjalan secara optimal, sehingga upaya peningkatan produksi per satuan luas (produktivitas) sulit dilakukan. Pernyataan tersebut benar adanya, namun perlu juga dipertimbangkan adanya keterbatasan sumberdaya khususnya lahan dan biaya, yang dimiliki petani, sehingga petani lebih memilih melaksanakan kegiatan usahataninya dengan resiko yang paling rendah. Sikap seperti inilah yang oleh Scott (1994) disebut sebagai moral ekonomi petani, khususnya petani kecil, yang hakiki, yaitu rasionalitas yang didasarkan kepada kemampuan sumberdaya yang dimilikinya. Jadi yang hendak dikatakan disini adalah pendidikan memang dibutuhkan untuk mendukung kemampuan seseorang dalam bekerja, namun hal tersebut tidaklah mutlak karena masih ada faktor lain yang menentukan seorang individu harus bersikap dalam pekerjaan yang digelutinya.
Gambar 2 memperlihatkan jumlah tenaga kerja di sektor pertanian wilayah pedesaan dan perkotaan berdasarkan tingkat pendidikan. Tingkat pertumbuhan tenaga kerja di sektor pertanian yang tidak pernah sekolah mengalami kenaikan sebesar 20,67 persen tiap tahun selama kurun waktu 20072009. Demikian halnya dengan tenaga kerja di sektor pertanian yang tidak tamat sekolah dasar yang meningkat lebih tinggi dibandingkan tenaga kerja sektor pertanian yang tidak pernah sekolah yaitu sebesar 28,99 persen tiap tahunnya. Hal ini menunjukkan kecenderungan bahwa sektor pertanian digeluti oleh mereka yang memiliki jenjang pendidikan yang lebih rendah karena mereka mungkin beranggapan untuk sebatas menjadi petani sesungguhnya tidak terlalu perlu melewati sebuah pendidikan formal tertentu dengan jenjang pendidikan yang lebih tinggi.

Pangsa terbesar tenaga kerja sektor pertanian dengan tingkat pendidikan sekolah dasar, pertumbuhannya menurun sebesar 15,38 persen tiap tahunnya. Diikuti oleh tenaga kerja sektor pertanian dengan tingkat pendidikan SLTP yang menurun 12,33 persen tiap tahunnya. Ada banyak faktor yang mempengaruhi penurunan ini, diantaranya adalah kesadaran masyarakat dalam mengecap pendidikan yang lebih tinggi atau mungkin keinginan masyarakat untuk bekerja di sektor non pertanian dengan jenjang pendidikan yang dimiliki tersebut. Sedangkan tingkat pertumbuhan tenaga kerja sektor pertanian pada 
Gambar 1. Perkembangan Tenaga kerja di Sektor Pertanian dan Non Pertanian di Provinsi Sulawesi Utara, 2000-2009 (Employment Growth in Agriculture and Non Agricultural Sector in North Sulawesi, Province 2000-2009)

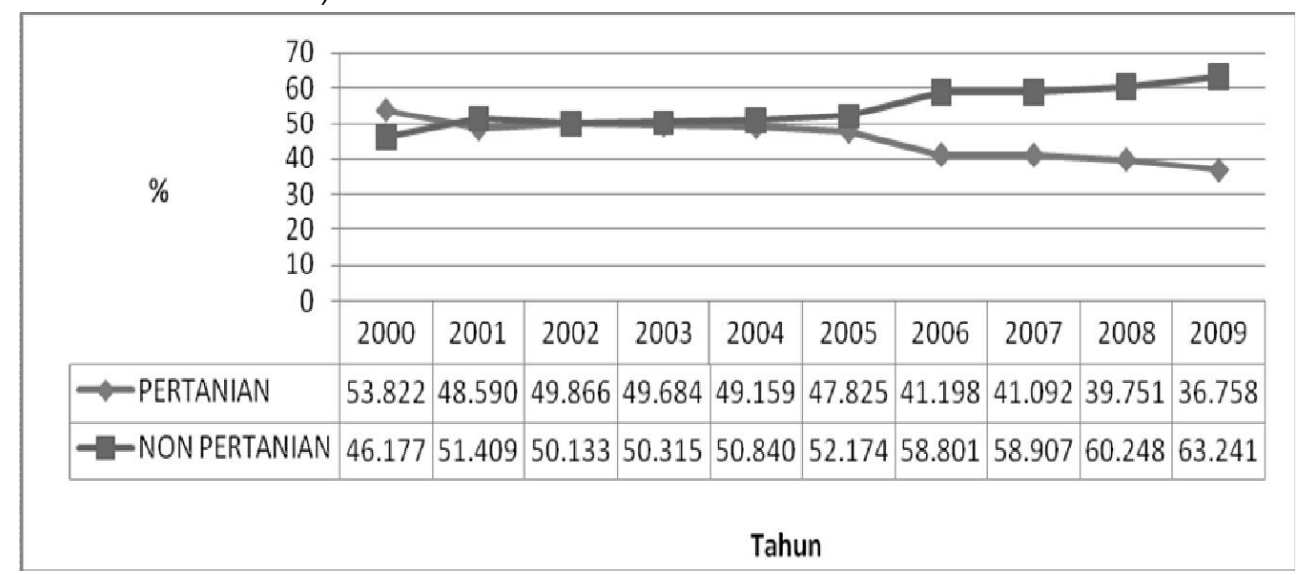

Sumber : diolah dari data sekunder, 2007 - 2009

tingkat pendidikan SMTA dan Diploma / Universitas mengalami kenaikan masing-masing sebesar 1,9 persen dan 11,34 persen tiap tahunnya selama kurun waktu 2007 - 2009. Hal ini cenderung mengindikasikan bahwa tenaga kerja dengan jenjang pendidikan yang lebih tinggi mulai menaruh minat di sektor pertanian khususnya di wilayah pedesaan.

\section{Dinamika Tenaga Kerja Sektor Pertanian Berdasar-kan Golongan Usia}

Usia petani akan mempengaruhi kemampuan fisik bekerja dan cara berfikir. Petani yang lebih muda biasanya cenderung lebih agresif dan lebih dinamis dalam berusahatani bila dibandingkan dengan petani yang lebih tua. Di samping itu, usia juga mempengaruhi seorang petani dalam mengelola usahataninya. Petani dengan usia yang relatif lebih muda akan mampu bekerja keras bila dibandingkan dengan petani yang lebih tua.

Gambar 3 memperlihatkan jumlah tenaga kerja di sektor pertanian wilayah pedesaan dan perkotaan dimana tingkat pertumbuhan tenaga kerja di sektor pertanian yang berusia 15-19 tahun meningkat 2,13 persen tiap tahunnya selama kurun waktu 2007-2009. Tetapi, tenaga kerja sektor pertanian dengan usia-usia produktif lainnya malah mengalami kemerosotan tiap tahunnya. Diantaranya tenaga kerja sektor pertanian dengan usia 2024 tahun menurun 16,65 persen tiap tahun diikuti oleh tenaga kerja sektor pertanian dengan usia 2529 tahun yang menurun sebesar 16,1 persen.
Sama halnya dengan tenaga kerja sektor pertanian usia 30-34 tahun dan 35-39 tahun, masing-masing mengalami penurunan 7,41 persen dan 2,28 persen tiap tahunnya. Begitu pula dengan tingkat pertumbuhan tenaga kerja sektor pertanian usia 40-44 tahun dan 45-49 tahun juga mengalami penurunan tiap tahunnya masing-masing sebesar 0,31 persen dan 7,42 persen. Sedangkan tenaga kerja sektor pertanian dengan usia 50-54 tahun dan 55 keatas meningkat masing-masing sebesar 10,93 persen dan 1,09 persen tiap tahunnya selama kurun waktu 2007-2009 Hal ini mengindikasikan tenaga kerja pertanian dengan golongan usia paling muda dan tua bersedia bekerja di sektor pertanian, kecenderungan mereka yang berusia muda bekerja di sektor pertanian mungkin karena diajak oleh orang tuanya untuk membantu orang tuanya bekerja bahkan dinamika tenaga kerja ini terjadi mungkin juga disebabkan karena adanya perubahan struktur usia tiap tahunnya.

Gambar 4 memperlihatkan jumlah tenaga kerja di sektor pertanian wilayah pedesaan dan perkotaan berdasarkan kabupaten/kota. Tingkat pertumbuhan tenaga kerja di sektor pertanian pada Kabupaten Bolaang Mongondow dan Kabupaten Minahasa masing-masing menurun sebesar15,1 persen dan 7,13 persen tiap tahunnya. Diikuti pula oleh tenaga kerja sektor pertanian di Kabupaten Kepulauan Sangihe dan Kabupaten Kepulauan Talaud yang masing-masing menurun sebesar 23,21 persen dan 7,14 persen. Tenaga kerja sektor 
pertanian di Kabupaten Minahasa Selatan juga menurun sebesar 29,92 persen tiap tahunnya. Diikuti pula oleh Kabupaten Minahasa Utara yang menurun sebesar 1,76 persen tiap tahunnya selama kurun waktu 2007-2009. Sama halnya dengan Kabupaten Bolaang Mongondow Utara, Kepulauan Sitaro, Minahasa Tenggara dan Kota Kotamobagu mengalami penurunan masingmasing sebesar 9,48 persen, 4,45 persen, 24,66 persen dan13,93 persen selama kurun waktu 2008-2009 karena pada tahun 2007 daerah ini masih gabung dengan induk. Tapi, tingkat pertumbuhan tenaga kerja sektor pertanian Kota Manado mengalami peningkatan sebesar 12,23 persen tiap tahunnya selama kurun waktu 20072009. Hal ini mengindikasikan warga Kota Manado mulai menaruh minat untuk berprofesi sebagai tenaga kerja pertanian khususnya di daerah perkotaan. Berbeda dengan tenaga kerja sektor pertanian di Kota Bitung dan Tomohon yang masing-masing mengalami penurunan sebesar 7,07 persen dan 7,63 persen tiap tahunnya.

\section{Dinamika Tenaga Kerja Sektor Pertanian Berdasarkan Curahan Jam Kerja}

Tenaga kerja (employed) dibedakan atas 3 macam, yaitu tenaga kerja penuh (full employed), tenaga kerja tidak penuh atau setengah pengangguran (under employed) dan tenaga kerja yang belum bekerja atau sementara tidak bekerja (unemployed). Tenaga kerja penuh adalah tenaga kerja yang mempunyai jumlah jam kerja > 35 jam dalam seminggu dengan hasil kerja tertentu sesuai dengan uraian tugas, sedangkan tenaga kerja setengah menganggur adalah tenaga kerja dengan jam kerja < 35 jam dalam seminggu. Tenaga kerja yang menganggur (unemployed) adalah tenaga kerja dengan jam kerja $0-<1$ jam per minggu dimana mereka mempunyai pekerjaan tetapi selama seminggu yang lalu tidak bekerja karena suatu sebab seperti sakit, cuti, menunggu panen dan mogok. Termasuk mereka yang sudah diterima bekerja tetapi selama seminggu yang lalu belum mulai bekerja.

Gambar 5 memperlihatkan jumlah tenaga kerja di sektor pertanian wilayah pedesaan dan perkotaan berdasarkan curahan jam kerja. Tingkat pertumbuhan tenaga kerja di sektor pertanian pada curahan jam kerja 0 (sementara tidak bekerja) meningkat sebesar 18 persen tiap tahunnya. Sedangkan tingkat pertumbuhan tenaga kerja sektor pertanian pada curahan jam kerja 1-14 jam, 15-34 jam dan 35 jam ke atas menurun masingmasing sebesar 14 persen, 4 persen dan 4 persen tiap tahunnya.

Hal ini mengindikasikan tenaga kerja yang bekerja penuh dan setengah pengangguran mulai berkurang, tapi mereka yang mempunyai pekerjaan tetap selama seminggu yang lalu tidak bekerja karena suatu sebab seperti sakit, cuti, menunggu panen dan mogok serta termasuk mereka yang sudah diterima bekerja tetapi selama seminggu yang lalu belum mulai bekerja mengalami peningkatan. Peningkatan ini cenderung disebabkan oleh banyak faktor diantaranya keinginan masyarakat untuk bekerja di sektor non pertanian sehingga lebih memilih menunggu mendapatkan pekerjaan yang lebih baik dibandingkan bekerja di sektor pertanian.

\section{KESIMPULAN DAN SARAN}

Tingkat pertumbuhan tenaga kerja sektor pertanian mengalami penurunan sebesar 5,78 persen per tahun dalam kurun waktu tahun 20002009. Sedangkan tenaga kerja di sektor non pertanian mengalami peningkatan 1,78 persen tiap tahunnya. Hal ini mengindikasikan terjadi kecenderungan transformasi struktural tenaga kerja sektor pertanian ke sektor non pertanian. Pangsa tenaga kerja sektor pertanian berdasarkan tingkat pendidikan didominasi oleh tingkat pendidikan sekolah dasar selama kurun waktu 2007-2009 tapi tingkat pertumbuhan tenaga kerjanya mengalami penurunan tiap tahun baik di wilayah pedesaan maupun perkotaan. Sedangkan pada jenjang pendidikan yang lebih tinggi yaitu Diploma/ Universitas mengalami peningkatan tiap tahunnya. 
Gambar 2. Jumlah Tenaga kerja di Sektor Pertanian Wilayah Pedesaan dan Perkotaan Berdasarkan Tingkat Pendidikan di Provinsi Sulawesi Utara, 2007-2009 (Total Employment in Agriculture Sector Rural and Urban Areas Based on Level of Education in North Sulawesi Province , 2007-2009)

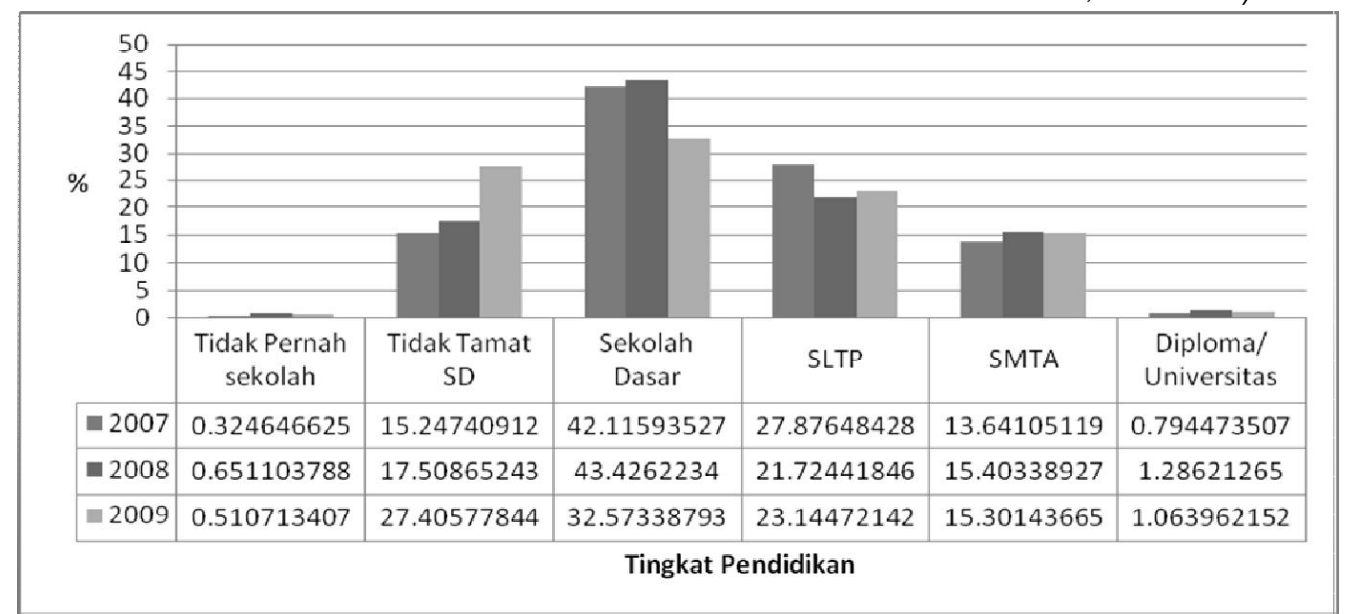

Sumber : diolah dari data sekunder, 2007 - 2009

Gambar 3. Jumlah Tenaga kerja di Wilayah Pedesaan dan Perkotaan Berdasarkan Golongan Usia di Provinsi Sulawesi Utara, 2007-2009 (Total Employment in Rural and Urban Areas Based on Age Group in North Sulawesi Province, 2007-2009)

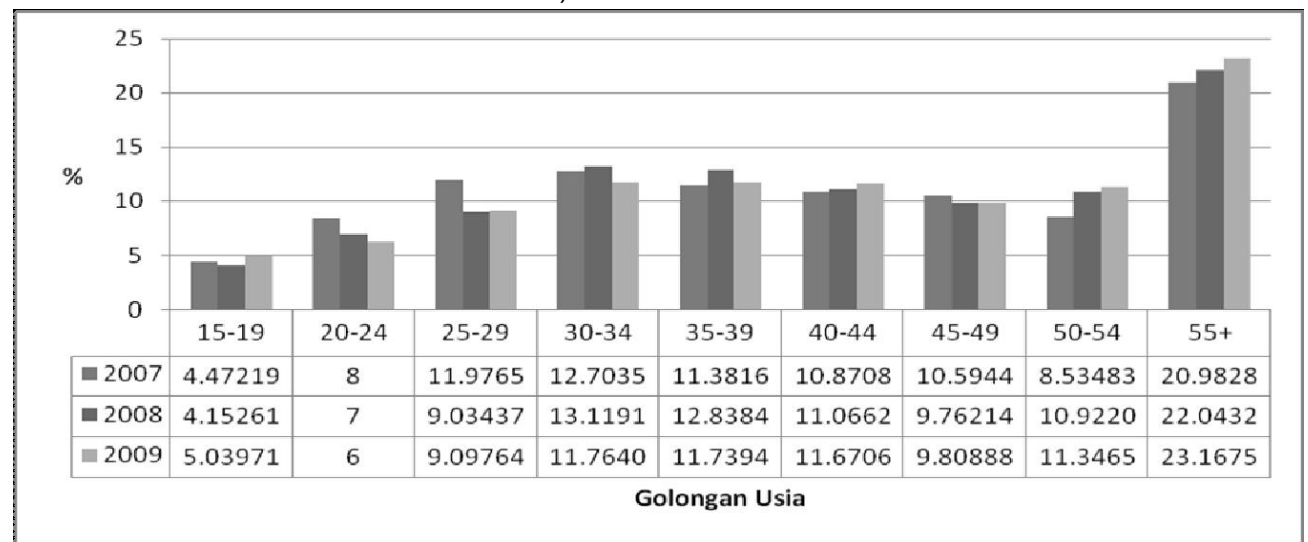

Sumber : diolah dari data sekunder, 2007-2009

Gambar 4. Jumlah Tenaga kerja di Wilayah Pedesaan dan Perkotaan Berdasarkan Kabupaten Kota di Provinsi Sulawesi Utara, 2007-2009 (Total Employment in Rural and Urban Areas by District Municipality in North Sulawes Province i, 2007-2009)

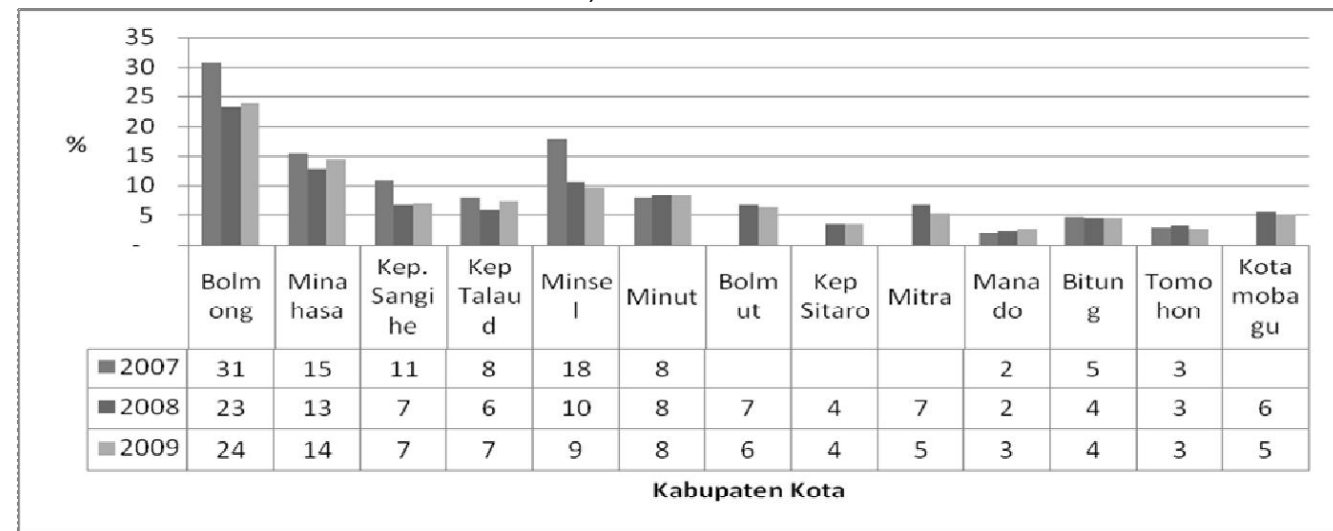

Sumber : diolah dari data sekunder, 2007- 2009 
Gambar 5. Proporsi Tenaga kerja di Sektor Pertanian pada Wilayah Pedesaan dan Perkotaan Berdasarkan Jam Kerja di Provinsi Sulawesi Utara, 2007-2009 (Proportion of Employment in Agriculture Sector in Rural and Urban Areas Based on Labor Hours in North Sulawesi Province, 2007-2009)

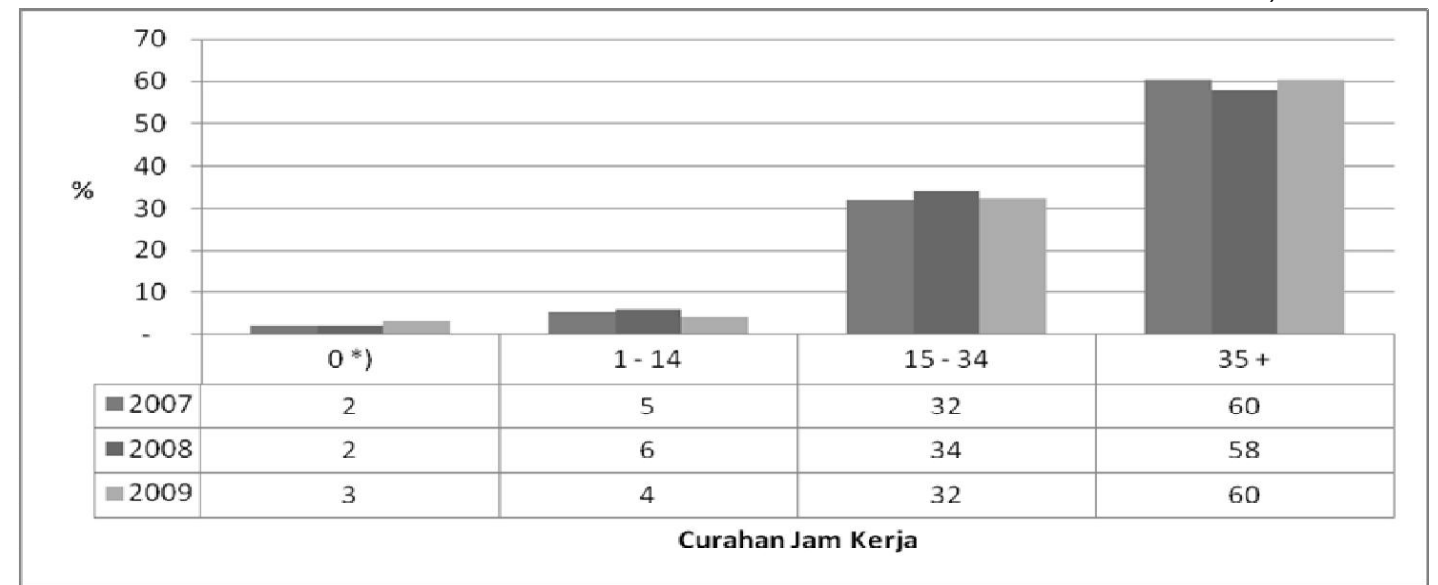

Sumber : diolah dari data sekunder, 2007 - 2009

Peningkatan jenjang pendidikan yang lebih tinggi cenderung mengindikasikan bahwa masyarakat mulai meminati sektor pertanian selama kurun waktu 2007-2009. Pangsa tenaga kerja sektor pertanian berdasarkan golongan usia didominasi oleh usia 55 tahun ke atas selama kurun waktu 2007-2009 dan mengalami peningkatan tiap tahunnya. Peningkatan tingkat pertumbuhan tenaga kerja di sektor pertanian juga terjadi pada usia 15-19 tahun dan 50-54 tahun. Usia produktif lainnya mengalami penurunan tiap tahunnya selama kurun waktu 2007-2009. Penurunan usia-usia produktif cenderung mengindikasikan bahwa tenaga kerja yang berusia muda kurang meminati sektor pertanian yang mungkin dianggap belum mampu memberi masukan yang berarti dari segi ekonomi sehingga dikuasai oleh usia non produktif. Pangsa tenaga kerja yang ada di sektor pertanian berdasarkan kabupaten/kota didominasi oleh Kabupaten Bolaang Mongondow selama kurun waktu 2007-2009 walaupun tingkat pertumbuhan tenaga kerja sektor pertaniannya mengalami penurunan tiap tahun. Peningkatan yang terjadi di Kota Manado dan penurunan yang terjadi di Kabupaten/Kota yang lain cenderung mengindikasikan bahwa tenaga kerja sektor pertanian menaruh minat yang lebih untuk bekerja di sektor pertanian di ibukota Provinsi Sulawesi Utara, karena mungkin adanya ketersediaan sarana dan prasarana yang menunjang dan jauh lebih baik dibandingkan di daerah asalnya. Pangsa tenaga kerja sektor pertanian berdasarkan curahan jam kerja didominasi tenaga kerja yang bekerja penuh (>35 jam) selama kurun waktu 2007-2009 meskipun terjadi penurunan tingkat pertumbuhan tenaga kerja baik di wilayah pedesaan maupun perkotaan tiap tahunnya.

Disarankan perlunya kerjasama dari pemerintah dan semua pihak yang terkait untuk meningkatkan kualitas pendidikan bagi tenaga kerja sektor pertanian. Antara lain dengan memberi penyuluhan dan insentif bagi masyarakat yang berusia muda agar tertarik untuk bekerja di sektor pertanian. Selain itu, peningkatan kualitas di tiap daerah yang meliputi Kabupaten/Kota harus dioptimalkan dan memperhatikan curahan jam kerja tenaga kerja sektor pertanian agar produktivitasnya meningkat.

\section{DAFTAR PUSTAKA}

Anonim, 2009. Pertumbuhan Ekonomi di Sulut meningkat, Pengangguran Meroket. http: //tribunmanado.co.cc/ diakses tanggal 3 Juli 2010

------, 2010. Tenaga Kerja Sektor Pertanian. http://www.datastatistik-indonesia.com/ diakses tanggal 3 Juli 2010

Bappeda, 2006. Rencana Pembangunan Jangka Menengah Daerah Provinsi Sulawesi Utara. Manado

BPS, 2000-2009. Statistik Indonesia. Jakarta 
----, 2007-2009. Keadaan Ketenagakerjaan Provinsi Sulawesi Utara. Sulawesi Utara

Disnakertrans, 2007. Profil Sumber Daya Manusia Indonesia. Jakarta

Maulana, Muhamad., dan Sudi Mardianto. 2007. Dinamika Tenaga Kerja Pertanian di Indonesia (Artikel Pemikiran Mubyarto). www.jurnal ekonomirakyat.com diakses tanggal 2 Juli 2010

Nani Siregar, Amelia. 2003. Perencanaan dan Aktivasi Sumber Daya Manusia di Sektor Pertanian. amelians03@yahoo. com diakses tanggal 27 Juli 2010

Scott, J.C. 1994. Moral Ekonomi Petani. LP3ES. Jakarta
Simanjuntak, P.J, 1995. Pengantar Ekonomi Sumberdaya Manusia. Lembaga Penerbit Fakultas Ekonomi Universitas Indonesia. Jakarta.

Soelaiman J., \& S. I. Santoso. 1986. Materi Pokok Dinamika Tenaga Kerja Sektor Pertanian Kelompok. Penerbit Karunika, Universitas Terbuka, Jakarta

Suroto, 1992. Strategi Pembangunan dan Perencanaan Kesempatan Kerja. Gajah Mada, Jakarta.

Swasono, T. 1987. Metode Perencanaan Tenaga Kerja Sektor Pertanian. PEE, Yogyakarta

Tjiptoherijanto, P. 1996. SDM dalam Pembangunan Nasional. Jakarta 